\title{
A Comparison of Corporate Governance and Tax Avoidance of UK and Japanese Firms
}

\author{
Bassem Salhi \\ Associate Professor, Department of Accounting, College of Business \\ Administration (CBA), Majmaah University, Majmaah, Saudi Arabia \\ e-mail: b.salhi@mu.edu.sa
}

\author{
Jabr Al Jabr \\ Assistant, Department of Accounting, College of Business Administration (CBA) \\ Majmaah University, Majmaah, Saudi Arabia, e-mail: j.aljabr@mu.edu.sa
}

\section{Anis Jarboui}

Full Professor, Sfax University, Tunisia, EM Normandie - France

e-mail: anisjarboui@yahoo.fr, anisjarboui01@em-normandie.fr

\begin{abstract}
The present study was designed to determine the relationship between corporate governance and tax avoidance in an international setting.

Financial and governance data sourced from the Datastream database for a sample of Japanese and UK firms between 2012 and 2017 are used. First, we examine the direct effect of several corporate governance mechanisms on tax avoidance. Second, we divide the full sample into two groups (common law and code law legal system) to explore the relationship between law, corporate governance, and tax avoidance. We use both univariate and feasible generalized least square (FGLS) regression methods to examine our hypotheses.

This study finds that the board size, independent directors, and the presence of women on boards of directors reduce the likelihood of tax avoidance. However, we find an insignificant association between ownership concentration and tax avoidance. Second, it also finds that firms in countries with higher country-level governance engage in less tax avoidance. The results also suggest that the role of corporate governance is more pronounced for firms operating in common law countries than those in code law countries.

This manuscript is one of the few studies that examine the relationship between corporate governance and tax avoidance in an international setting with different legal
\end{abstract}


and institutional environment. This relationship differs across the two countries. This paper clearly identifies implications for research, practice, and society. It documents that when a country implements a good system of governance, which targets improving transparency and accountability, it will lead to less corporate tax avoidance.

Keywords: tax avoidance, corporate governance, comparative legal system

JEL: H25, H26, H32, H71, G32, G38

\section{Introduction}

The taxation of firms was considered a non-strategic activity of a technical nature whose governance was left to a group of experts of the firm. The tax department was rarely questioned, nor was there any follow-up by the board of directors or shareholders. The financial scandals of recent years have greatly changed the role of the tax function within companies. On the one hand, regulators, tax authorities, analysts, and other stakeholders pay more attention to large firms. On the other hand, the responsibilities assigned to boards of directors are broadened and now include the problem of tax evasion.

The extent, determinants, and consequences of tax evasion and corporate aggression have been topical issues.

There are many explanatory factors for tax evasion, which can act as an incentive or a constraint (Gul et al. 2018). Some of the incentive factors include pressure from shareholders and creditors, as well as certain specific contexts, such as capital increases or changes in management. Constraining factors include the accounting rules used (IFRS or other standards), the legal protection system ("common law" as opposed to "code law") and governance mechanisms, such as the ownership structure (Desai and Dharmapala 2008; Heitzman 2010) and board of directors (Minnick and Noga 2010; Khan et al. 2017; Armstrong et al. 2015; Richardson et al. 2016; Lanist et al. 2018; Muhammad and Yan 2019). Since La Porta et al. (1998, 2002), many studies in the law and finance literature have shown that institutional differences, e.g., the legal system, may affect corporate decisions, such as tax strategies (e.g., Anderson and Gupta 2009; Kanagaretnam et al. 2016).

The institutional context can also influence the power of shareholders in matters of governance. La Porta et al. (1999) showed that the dispersion of shareholding is associated with a significant protection of the interests of the shareholders. The legal protection system includes two elements: rules, which protect the interests of minority shareholders to a greater or lesser extent (the possibility to contest matters at general meetings, to vote by internet, etc.), and the capacity of shareholders to enforce their rights before the courts (inexpensive legal action, for example, class action suits, or higher penalties imposed on "cheaters" by the courts, etc.). The level of investor protection seems to influence the quality of accounting information. Leuz et al. (2003) 
measured weaker management of results in common law countries, such as the United States and the United Kingdom, where shareholders are better protected and stock markets more developed than in code law type countries, such as Japan or the countries of Continental Europe.

The purpose of this study is to examine the effect of the board of directors' characteristics and ownership concentration on corporate tax avoidance in two countries (UK and Japan) with different legal origins (common law and code law) and business culture. This study addresses two questions: (1) does corporate governance influence corporate tax evasion? And (2) do diverse corporate governance mechanisms have a dissimilar impact on corporate tax evasion in different legal systems? The paper is organized as follows. Section 1 provides the theoretical background and hypotheses for the study. Section 2 describes the methodology used. Section 3 reports the results of the empirical study.

\section{Literature review and hypotheses development}

\section{Tax avoidance and corporate governance}

Dyreng et al. (2008) define tax evasion via the accounting transactions that exercised the tax liability of the company. This definition is not the dissimilarity of the different realities in a fiscal tax, the activities of a tax-deferred business challenge and the fiscal taxes of (Haned and Heitzman 2010). There is an important distinction between tax evasion and tax avoidance. Tax avoidance is the result of measures taken to minimize tax and which, while in keeping with the letter of the law, are contrary to the purpose and spirit of the law. When these arrangements are in keeping with the spirit of the law, we are talking about effective tax planning. Tax evasion refers to deliberately ignoring a specific part of the law. Tax evasion, unlike tax avoidance, has criminal consequences. In this study, we use the term aggressive tax planning, which encompasses the concepts of tax avoidance and tax evasion. We have made this choice because we cannot isolate companies that undertake tax avoidance from those that can undertake tax evasion (Chen et al. 2010; Lanis and Richardson 2012; Minnick and Noga 2010; Armstrong et al. 2015; Richardson et al. 2016; Kanagaretnam et al. 2016; Khan et al. 2017; Lanis et al. 2018; Muhammad and Yan 2019). Gohet et al. (2017) found that the cost of the shares of companies that avoided taxes was lower and, as a result, their market valuation was higher. The purpose of limiting tax evasion is to protect the interests of all stakeholders in the firm. It is thus an integral part of Stakehoders governance. Stakeholder governance is interested in the relationships the company has with its various stakeholders in order to achieve its objectives. Ortas and Gallego-Álvarez (2020) support the idea that those firms achieving high corporate governance performance are less likely to engage in aggressive tax practices. 
The firm must take into account the expectations of all stakeholders and not just the shareholders. One of the most effective ways to manage financial risk is to put in place corporate governance that includes proactive risk management, listening to stakeholders, and transparent communication about the problems faced by the firm.

\section{Board characteristics and tax avoidance}

The board of directors is one of the main governance mechanisms (Jensen 1993). For that reason, several studies have examined the effect of the characteristics of boards of directors on corporate tax evasion (Minnick and Noga 2010; Lanis and Richardson 2011; Richardson et al. 2016; Lanis et al. 2018).

\section{Board size}

Jensen (1993) argues that when the size of the board is not large, it has effective control, but when it is large and less relevant, it becomes difficult to control the CEO. Previous studies suggest that the size of the board has a negative effect on a company's market valuation (e.g., Yermack 1996). More recently, Nguyen et al. (2016) found that firms with a large board achieve significantly lower market values. However, other research (e.g., Boone et al. 2007) has shown that the perfect board size depends on different characteristics of the company and consequently does not contribute to greater performance. Hoseini et al. (2019) found that firms with a larger board of directors are associated with more tax avoidance. In short, we can suggest that the effect of the size of the board on the value of the company is the subject of debate. While some authors insist on the mischiefs of a large board of directors, others prove the opposite.

\section{H1: Board size is negatively related to tax avoidance.}

\section{Director independence}

The composition of the board of directors plays a role in a company's financial transparency and reduces deficient behavior such as financial fraud; it can be assumed that the composition of the board of directors influences the level of tax evasion carried out by the firm.

The composition of the board of directors is a factor that determines the board's effectiveness; the board of directors must take into account the common interests of all shareholders (Fama 1980; Fama and Jensen 1983).

Independent directors are considered good controllers who act in the best interests of the firm to develop a good reputation as experts in control. The viability of the board can be improved by including external members. Lui et al. (2015) found that independent directors have an overall positive effect on firm operating performance. Moreover, Reguera-Alvarado and Bravo (2017) showed that the presence of independent directors on a board improves firm performance. Minnick and Noga (2010) postulated that in- 
dependent directors can consolidate tax avoidance practices because they can supply essential knowledge and basic perceptions from their own sector and practice. Chytis et al. (2020) showed a significant positive association of board independence with tax planning, while Richardson et al. (2016) found a positive relationship between effective tax rate and independent directors. However, according to Lanis and Richardson (2011), the significant presence of independent directors on the board can increase its control effectiveness.

H2: The presence of independent directors is negatively related to tax avoidance.

\section{Women on the board and tax avoidance}

Activism that has developed around gender diversity in corporate governance bodies testifies to complex societal issues. Gender diversity has become ubiquitous in corporate governance thinking. It is part of a new approach to governance aimed at overcoming the shortcomings of the traditional conception, especially regarding the taking into account of the creative potential of the board in the production of value (Adams and Ferreira 2009). Women directors make specific contributions in terms of experiences, perspectives, and management styles, compared to male directors (Gregory et al. 2015; Smith et al. 2014). Kastlunger et al. (2010) predicted that women are stricter in tax compliance. However, men are less demanding (the gender effect). According to Richardson et al. (2016) and Zhou and Li (2018), the presence of women on a board reduces tax avoidance activities. Since women are generally better controllers, they behave the same way when they are dependent/independent administrators. They are relevant in reducing tax evasion. Jarboui et al. (2020) showed that the level of tax avoidance decreases when the number of women on the board increases.

H3: Gender diversity is negatively related to tax avoidance.

\section{Ownership concentration and tax avoidance}

The relationship between ownership structure and taxes is also important (Desai et al. 2007b; Desai and Dharmapala 2008). If the owner is the majority, he will issue his tax maneuvers. When the manager has succeeded, he is likely to expropriate the shareholder's way through tax evasion (Richardson et al. 2016). Concentrated property firms, Chen et al. (2010) can avoid being attributed to owners who control the desirability of savings. Klassen (1997) also thinks of companies with a higher tax avoidance, taxes can be avoided, however. On the other hand, family firms may avoid fewer taxes due to the potential costs of tax avoidance. Badertscher et al. (2013) found that ownership concentration is negatively associated with tax avoidance. However, Khan et al. (2017) found a positive relation between ownership concentration and tax avoidance. Cabello et al. (2019) found that firms with a greater concentration of management ownership avoid less tax, while Richardson et al. (2016) revealed a significant 
but non-linear relationship between concentration of ownership and tax evasion. The authors argue that the concentration of ownership through voting rights is negatively related to tax evasion because of the convergence of interest effect.

\section{H4: Ownership concentration is negatively related to tax avoidance.}

\section{Law, corporate governance, and tax avoidance}

Our paper seeks to examine the practice of tax evasion in an international context. In the current literature, one of the approaches pursued to explain the disparities in this practice between countries is based on the disparities in the legal specificities of those countries (Daniel et al. 2012). A distinction is generally made between countries with a "common law" type legal system, built essentially on case law and aimed at defending the interests of private parties, and countries with a "civil law" type legal system, with a civil or codified law, whose objective is to defend the interests of the State (La Porta et al. 1998). This approach is today known as the legal-financial approach or the 'Law and Finance' approach. Corporate governance in the European Union is very heterogeneous, and the system is extremely varied from one country to another: a civil law model, a common law model, and a hybrid model (Kubíček et al. 2016).

The EU was built around two different legal systems. The first system includes countries belonging to the civil law tradition and which is also subdivided into two branches: the "French" branch and the "Germanic." The French branch inspired bordering and North Mediterranean countries, namely Belgium, Luxembourg, and the Netherlands, as well as Spain, Portugal, Italy, and Romania. The Germanic branch is represented by Germany and Austria, and to which we can add Central and Eastern European countries (Poland, Estonia, Latvia, Lithuania, the Czech Republic, Slovakia, Hungary, Slovenia, and Bulgaria) since the end of communism (Yeoh 2007). However, there is a sub-group, i.e., the Nordic countries, to which Denmark, Sweden, and Finland belong.

The second system includes countries under the common law system, namely England, Wales, and Ireland. Filatotchev et al. (2013) argue that board efficiency, the concentration of ownership, and incentives for executives can vary with the legal system and institutional specificities of a given country. Several studies suggest that the dichotomy of legal systems between "common law" and "civil law" influences tax evasion. They argue that in civil law countries, accounting regulation seems to be subject to strong political pressure from the state, which establishes and imposes the accounting rules. It follows that the accounting rules in civil law countries offer "insiders" a great deal of latitude to make manipulations to the detriment of the production of quality accounting information.

In contrast, accounting in common law countries seems to be directed more towards protecting the interests of private parties and serving, inter alia, the interests of investors Besides et al. (2004). According to governance theory, tax evasion by CEOs can be moderated or reduced by using various governance mechanisms. The compo- 
sition of the board of directors (size, independence, and structure) and the ownership structure are examples of these mechanisms. However, their effectiveness in reducing CEOs' use of tax evasion appears to vary from country to country.

According to the legal and financial approach, tax evasion could be influenced by the level of legal protection that a country offers to its investors. In this context, it is considered to be less important in common law countries, which offer better legal protection to "outsiders" and which have a better quality of application of the rules of rights (Anderson and Gupta, 2009). Therefore, it should be more important in civil law countries, which are characterized by weak legal protection of outsiders and where rights are poorly enforced. Zeng (2019) found that firms that are resident in countries with stronger country-level governance engage in less tax avoidance. Beekes et al. (2016) found better disclosure in common law countries compared to code law countries. As discussed above, common law is more efficient than code law. So, we predict that the impact of corporate governance mechanisms (boards of directors and ownership concentration) will be more pronounced in common law countries than in code law countries.

H5: The impact of corporate governance on tax avoidance is more pronounced in common law countries than in code law countries.

\section{Research methodology}

In this section, we will detail the methodology. It includes the selection of the sample and the rationale for that selection. The specification of the empirical model, the operationalization of the variables, and the measures are also examined here.

\section{Sample selection and data}

United Kingdom and Japan are two typical countries in such comparative studies between common law and code law legal systems.

We chose these two countries for several reasons. First, corporate tax avoidance has been a major issue and is widespread in several countries located in Asia-Pacific markets (Japan is an example) (Gul et al. 2018). Second, UK and Japan have different cultures and traditions. UK follows the accounting standards used for the preparation of financial information based on the common law accounting system. By contrast, Japan is an Asian country that has a code law accounting system.

The sample consists of firms that were included in the FTSE Eurotop 100 index on December $30^{\text {th }}, 2011$. For several reasons, not all FTSE Eurotop 100 index listed firms are included in the sample of this study. The final sample consists of 52 firms (312 firm-year observations). Twenty-three of the 100 firms are excluded from the sample because they are financial companies. The necessary financial data was not available for every firm for such a long period, which is the case for 25 firms in the 
sample. Our initial sample comes from Japanese firms covered by the TOPIX 100 index names made by the Tokyo Stock Exchange in January 2012 and December 2017. The final sample consists of 330 observations over a firm year. Table 1 presents details of the two countries.

Table 1. UK and Japan characteristic's comparison

\begin{tabular}{|l|c|c|}
\hline & UK & Japan \\
\hline Tax avoidance ETR (2012-2017)* & 23.22 & 30.12 \\
\hline Legal origin & Common & Code \\
\hline Tax revenues in (2012)/GDP in \% & 25.63 & 9.86 \\
\hline Market capitalization (2012)/GDP in \% & 6 & 8 \\
\hline
\end{tabular}

* ETR is the dependent variable indicating the Corporate tax avoidance.

Source: authors' own compilation.

\section{Variable measures}

\section{Tax avoidance}

ETR is a measure of tax avoidance (Cash Effective Tax Rate). Following previous studies (Dyreng et al. 2008; Chen et al. 2010; McGuire et al. 2014; Chan et al. 2016; Dyreng et al. 2017).

$$
\text { ETR }_{i t}=\frac{\text { TaxExpense }_{i t}}{\text { PretaxIncome }_{i t}}
$$

Obviously, there are differences not only between different contexts but also between European countries because corporate income taxes are not harmonized within the EU. Specifically, statutory tax rates from European countries differ considerably. Countries like Belgium and France have high tax rates. However, Poland and other Eastern European countries have rather low tax rates (Thomsen and Watrin 2018). Thomsen and Watrin found that the average EU cash ETR, which indicates corporate tax avoidance, is $25.04 \%$. This rate is limited between UK and Japan. Janský (2019) documented that in the EU, "the lowest ETRs are to be found in Hungary (7.5\%), Bulgaria (9.5\%), Cyprus (9.6\%) as well as in the Netherlands (10.4\%) and Latvia (10.6\%). Within the EU, Italy and Greece have the highest ETR (30.4\% and $28.4 \%$ respectively), with the third and fourth highest being Spain and Slovakia (21.8\% and 20.2\% respectively)." 


\section{Characteristics of the board of directors}

Board size (BS) is calculated as the total number of members of the board of directors (Anderson and Reeb, 2003; Reguera et al. 2017).

Director independence (IND) is measured as the percentage of independent directors sitting on the board (Reguera et al. 2017).

Female directors: Following Terjesen et al. (2015) and Luo et al. (2017), the presence of female directors (WOM) is measured as the ratio of the number of women serving on the board to the total number of directors on the board (Table 2).

Ownership concentration (CONC) is calculated as the total proportion of outstanding shares of shareholders who hold at least $5 \%$ of outstanding shares (Munisi et al. 2014; Nguyen et al. 2015).

Table 2. Variable definitions

\begin{tabular}{|l|l|}
\hline \multicolumn{1}{|c|}{ Variable } & \multicolumn{1}{c|}{ Definition } \\
\hline Effective tax rate (ETR) & Tax expense/Pre-tax income \\
\hline Independent directors (IND) & Percentage of independent directors sitting on the board \\
\hline Female directors (WOM) & Percentage of female directors sitting on the board \\
\hline Board size (BS) & The number of directors on the board \\
\hline Ownership concentration (CONC) & $\begin{array}{l}\text { The total proportion of outstanding shares of shareholders who } \\
\text { hold at least 5\% of outstanding shares }\end{array}$ \\
\hline Firm size (SIZE) & Natural logarithm of total assets \\
\hline Return on assets (ROA) & Pretax income/Total assets \\
\hline Leverage (LEV) & Total debt/Total equity \\
\hline
\end{tabular}

Source: authors' own compilation.

\section{Control variables}

To control the effects of firm size, we introduced this variable (SIZE). Since the size of the firm is considered a key variable for tax evasion, we introduced the variable SIZE measured by the logarithm of the total assets (Slemrod 2007). Large firms are likely to be aggressive on the tax side. They possess economic and political power in comparison with small firms. Return on assets (ROA) is measured as pre-tax income divided by total assets (Mafrolla and D'Amico, 2016). Firms practice tax evasion to expand their returns. Leverage (LEV) is measured as total debt divided by total equity of firm $i$ at the end of fiscal year $t$. The correlation between the level of indebtedness and tax avoidance has been highlighted by several studies (e.g., Mafrolla and D'Amico 2016; Salehi and Salami 2020). 


\section{The regression model}

To examine the association between the board of directors, ownership concentration, and tax avoidance, we estimated the following tax avoidance model:

$$
\begin{aligned}
& \text { ETRit }=\beta 0+\beta 1 \text { BSit }+\beta 2 \text { INDit }+\beta 3 \text { WOW it }+\beta 4 \text { CONCit }+\beta 5 \text { SIZEit }+ \\
& \beta 6 \text { ROAit }+\beta 7 \text { LEV it }+\beta_{8} \text { COUNTRY fixed effect }{ }_{i t}+ \\
& \beta_{9} \text { YEAR fixed effect }{ }_{i t}+\varepsilon_{i t}
\end{aligned}
$$

Following previous research, we introduced several control variables in our model, and we added dummy variables to control for country and year fixed effects (COUNTRY and YEAR).To test our empirical model, we use a feasible generalized least squares (FGLS) regression. To overcome the potential problem of heteroskedasticity, the FGLS estimator can easily be performed and will result in an asymptotic estimator that is more efficient and tests more powerfully than the OLS estimator.

\section{Results and discussions}

\section{Descriptive statistics and difference in mean}

Table 3. Pearson correlations for independent variables

\begin{tabular}{|l|c|l|l|l|l|l|l|l|}
\cline { 2 - 8 } \multicolumn{1}{c|}{} & BS & IND & WOM & CONC & SIZE & ROA & LEV & VIF \\
\hline BS & 1.000 & & & & & & & 1.37 \\
\hline IND & $0.124^{* * *}$ & 1.000 & & & & & & 2.06 \\
\hline WOM & $0.109^{* *}$ & $0.423^{* *}$ & 1.000 & & & & & 1.42 \\
\hline CONC & $-0.117^{* *}$ & $0.256^{*}$ & -0.106 & 1.000 & & & & 1.23 \\
\hline SIZE & $0.394^{* * *}$ & $0.489^{* * *}$ & $0.504^{* *}$ & $-0.103^{* *}$ & 1.000 & & & 2.09 \\
\hline ROA & -0.107 & $0.362^{* * *}$ & $0.418^{* * *}$ & $0.181^{* * *}$ & $0.147^{* * *}$ & 1.000 & & 1.16 \\
\hline LEV & 0.084 & -0.057 & 0.176 & -0.074 & 0.134 & -0.097 & 1.000 & 1.31 \\
\hline
\end{tabular}

****** Indicate that the estimated coefficients are statistically significant with two-tailed p-values at the 10 percent, 5 percent, and 1 percent levels respectively.

Source: authors' own elaboration.

The Pearson correlations between the independent variables are not high (Table3). We have, for example, a significant correlation of 0.504 between firm size (SIZE) and the presence of female directors (WOM) on the board. Multicollinearity was also checked by calculating the variance inflation factors (VIF). 
Table 4. Univariate test difference (312 British and 330 Japanese firm-year observations).

\begin{tabular}{|c|c|c|c|}
\hline Variable & & Mean & t-test \\
\hline \multirow{2}{*}{ BS } & UK & 11.96 & \multirow{2}{*}{-0.64} \\
\hline & Japan & 10.23 & \\
\hline \multirow{2}{*}{ IND } & UK & 0.56 & \multirow{2}{*}{$-14.21^{* * *}$} \\
\hline & Japan & 0.28 & \\
\hline \multirow{2}{*}{ WOM } & UK & 0.14 & \multirow{2}{*}{$-14.67^{* * *}$} \\
\hline & Japan & 0.03 & \\
\hline \multirow{2}{*}{ CONC } & UK & 0.17 & \multirow{2}{*}{0.65} \\
\hline & Japan & 0.13 & \\
\hline \multirow{2}{*}{ SIZE } & UK & 9.12 & \multirow{2}{*}{$12.51^{* *}$} \\
\hline & Japan & 7.34 & \\
\hline \multirow{2}{*}{ ROA } & UK & 0.11 & \multirow{2}{*}{7.42} \\
\hline & Japan & 0.08 & \\
\hline \multirow{2}{*}{ LEV } & UK & 0.23 & \multirow{2}{*}{$-0.27^{* *}$} \\
\hline & Japan & 0.28 & \\
\hline
\end{tabular}

****** Indicate that the estimated coefficients are statistically significant with two-tailed p-values at the 10 percent, 5 percent, and 1 percent levels respectively.

Source: authors' own compilation.

VIF is not high, which leads to the rejection of the multicollinearity problem between the independent variables of our model. Table 4 presents the mean of the test and control variables for the British and Japanese samples. There is no significant difference in the size of the board (BS) between the two samples. As expected, the mean of independent directors (IND) for British firms is statistically higher than for Japanese firms. Also, the mean of female directors (WOM) is statistically higher for British firms. We found a statistically insignificant difference in the ownership concentration (CONC) between British firms and Japanese firms. The British firms are, on average, larger than the Japanese firms.

\section{Discussion of findings}

Table 5 presents the regression results of the tax avoidance model tested over the entire sample of 312 British and 330 Japanese firm-year observations.

We applied the modified Wald test to check for heteroscedasticity; the test is significant at the $1 \%$ level. Therefore, in order to carry out more detailed empirical work, it is essential to overcome the problem of heteroscedasticity. To do this, we used FGLS. The Wald test is significant at the $1 \%$ level, so corporate tax avoidance is well explained by our independent variables in the model. The results obtained and summarized in Table 5 show that the board of directors and ownership concentration reduce corporate tax avoidance. 


$$
\begin{gathered}
\text { ETR }_{\mathrm{it}}=\alpha_{0}+\beta_{1} \mathrm{BS}_{\mathrm{it}}+\beta_{2} \mathrm{IND}_{\mathrm{it}}+\beta_{3} \text { WOW }_{\mathrm{it}}+\beta_{4} \mathrm{CONC}_{\mathrm{it}}+\beta_{5} \text { SIZE }_{\mathrm{it}}+ \\
\beta_{6} \mathrm{ROA}_{\mathrm{it}}+\beta_{7} \mathrm{LEV}_{\mathrm{it}}+\beta_{8} \text { COUNTRY fixed effect }_{\mathrm{it}}+ \\
\beta_{9} \text { YEAR fixed effect }_{\mathrm{it}}+\varepsilon_{\mathrm{it}}
\end{gathered}
$$

\begin{tabular}{|c|c|c|c|c|c|}
\hline Variable & (1) & (2) & (3) & (4) & (5) \\
\hline Constant & 0.127 & 0.188 & 0.399 & 0.263 & 0.752 \\
\hline BS & $-0.253^{* * *}$ & $0.028^{* * *}$ & & & \\
\hline IND & $-0.389^{* *}$ & & $-0.382^{*}$ & & \\
\hline WOM & $-0.163^{* *}$ & & & $-0.269^{* *}$ & \\
\hline CONC & 0.112 & & & & $0.314^{* *}$ \\
\hline SIZE & 0.058 & $-0.284^{* * *}$ & $-0.096^{* * *}$ & -0.074 & 0.068 \\
\hline ROA & 0.263 & 0.036 & $0.426^{* * *}$ & $0.062^{*}$ & 0.195 \\
\hline LEV & $-0.048^{* * *}$ & $-0.058^{* *}$ & $-0.041^{*}$ & $-0.082^{* *}$ & $-1.203^{*}$ \\
\hline Country fixed effects & YES & YES & YES & YES & YES \\
\hline Year fixed effects & YES & YES & YES & YES & YES \\
\hline Hausman test & 1.77 & & & & \\
\hline Modified Wald test & $3.8^{\mathrm{e}+06 * * *}$ & & & & \\
\hline Wald test & $39.31^{* * *}$ & $77.14^{* * *}$ & $52.23^{* * *}$ & $45.96^{* * *}$ & $49.72^{* * *}$ \\
\hline
\end{tabular}

Table 5. FGLS regression analysis

****** Indicate that the estimated coefficients are statistically significant with two-tailed p-values at the 10 percent, 5 percent, and 1 percent levels respectively.

Source: authors' own elaboration.

Board size $(\mathrm{BS})$ is significantly and negatively $(\beta 1=-0.253$ and $\mathrm{p}<1 \%)$ associated with corporate tax avoidance, thus verifying $\mathrm{H} 1$. A large board makes it possible to pool a variety of resources, skills, and experiences that will benefit the management and control of tax evasion. As expected in hypothesis $\mathrm{H} 2$, the independence of the board of directors is a factor in reducing opportunistic accounting practices $(\beta 2=-0.389$ and $\mathrm{p}<5 \%$ ). These latest results confirm that the presence of independent directors on the board of directors increases the effectiveness of management control and encourages them to disclose more reliable financial information. These independent directors use their special skills and secondments to control the actions of the directors.

The results of a logit regression used by Lanis and Richardson (2011) for a sample based on 32 companies, including 16 companies with aggressive taxation and $16 \mathrm{com}-$ panies with non-aggressive taxation, show that the involvement of one more large proportion of outside board members reduces the risk of tax aggression. Lanis and Richardson's sensitivity review backs up our key findings regarding board composition and tax aggression. Also, the results show a negative and significant relationship $(\beta 3=-0.163$ and $p<5 \%)$ between the proportion of women (WOW) on their boards and corporate tax avoidance. The presence of women on corporate boards has gained much importance due to their effective role in monitoring managerial performance. Lanis and Richardson (2016) reveal that women's presence on corporate boards can exert 
a significant influence on reducing tax avoidance. Hoseini et al. (2019) showed that the presence of women on corporate boards reduces corporate tax avoidance, while Jarboui et al. (2020) showed that the level of tax avoidance decreases when the number of women on the board increases.

However, regarding the ownership structure variable, our results show that the effect of concentration (CONC) is not significant and positive $(\beta 4=0.112)$. This result does not agree with hypothesis H3. The concentration of shareholding is not associated with a lower intensity of tax evasion. The absence of a relationship observed by several authors in different contexts reflects, in particular, the two antagonistic effects of the concentration on tax evasion (alignment as opposed to entrenchment). This observation valid the assumption of passivity of control blockholders.

Regarding the control variables, during the analyzed period, the size (SIZE) and performance (ROA) of the company do not significantly affect tax evasion. However, the level of debt $(\beta 7=-0.048$ and $p<1 \%)$ has a significant effect. For highly indebted firms, the interest shown by their partners (creditors in particular) in their sustainability and, therefore, in their profitability, encourages tax evasion. In addition, firms whose financial health is the most precarious are more likely to engage in tax evasion.

The supplemental results are shown in Table 6 . They are derived from separate analyses of 312 British and 330 Japanese firm-year observations.

$$
\begin{aligned}
\text { ETR }_{\text {it }}= & \alpha_{0}+\beta_{1} \mathrm{BS}_{\mathrm{it}}+\beta_{2} \mathrm{IND}_{\mathrm{it}}+\beta_{3} \mathrm{WOW}_{\mathrm{it}}+\beta_{4} \mathrm{CONC}_{\mathrm{it}}+\beta_{5} \mathrm{SIZE}_{\mathrm{it}}+ \\
& \beta_{6} \mathrm{ROA}_{\mathrm{it}}+\beta_{7} \mathrm{LEV}_{\mathrm{it}}++\beta_{8} \text { YEAR fixed effect }_{\mathrm{it}}+\varepsilon_{\mathrm{it}}
\end{aligned}
$$

Table 6. FGLS regression: UK common law and Japan code law comparison

\begin{tabular}{|l|c|c|}
\hline \multicolumn{1}{|c|}{ Variable } & UK (312) & Japan (330) \\
\hline Constant & 0.424 & 0.293 \\
\hline BS & $-0.109^{* *}$ & $-0.064^{*}$ \\
\hline IND & $-0.346^{* * *}$ & -0.172 \\
\hline WOM & $-0.042^{*}$ & $-0.067^{*}$ \\
\hline CONC & $-0.132^{* *}$ & -0.186 \\
\hline SIZE & 0.059 & 0.171 \\
\hline ROA & 0.243 & 0.483 \\
\hline LEV & 0.124 & $-0.189^{* *}$ \\
\hline Year fixed effects & Yes & Yes \\
\hline Hausman test & $28.34^{* * *}$ & $26.67^{* * *}$ \\
\hline Modified Wald test & $2.7^{\text {e5*** }}$ & $6.0^{\text {e6** }}$ \\
\hline Wald test & $35.18^{* * *}$ & $21.69^{* * *}$ \\
\hline
\end{tabular}

****** Indicate that the estimated coefficients are statistically significant with two-tailed p-values at the 10 percent, 5 percent, and 1 percent levels respectively.

Source: authors' own compilation. 
Table 6 shows a negative relationship between board size (BS) and corporate tax avoidance in both samples of British $(\beta 1=-0.109$ and $p<5 \%)$ and Japanese firms ( $\beta 1=-0.064$ and $\mathrm{p}<10 \%)$. According to Table 4 , there is an insignificant difference for board size between the two samples. The coefficient for independent directors (IND) is negatively significant $(\beta 2=-0.346$ and $\mathrm{p}<1 \%)$ for the British sample. In contrast to Japanese firms, IND is statistically insignificant for the Japanese firms. Few Japanese companies have adopted rules of structuring their board of directors inspired by North American standards. "American-style" governance standards are not very effective in Japanese culture, in which absolute loyalty is demanded in exchange for a contract, and where it is traditionally unthinkable to question authority or to express disagreement.

This example also shows that rules like governance cultures are not universal. They can favor the emergence of group thinking within boards of directors. The coefficient relating to the variable (WOW) is significant for both British and Japanese samples. This result reveals that despite the differences between the British and Japanese socio-economic environments, and despite the relatively low importance of the presence of women in top management, we empirically found that their presence has a negative influence on tax evasion. Thus, the presence of women in the TOP management of large companies is probably a significant resource that results in ethical and transparent behavior.

The coefficient for ownership concentration (CONC) is also statistically significant for British firms and insignificant for Japanese firms, but in both samples, CONC is positive. This relationship differs between the two countries. Ownership concentration negatively impacts corporate tax avoidance because blockholders are aware of the potential costs, such as firm reputation and penalties (Hanlon and Heitzman, 2010). British firms (low concentration) show that tax evasion is strongly determined by contextual motivations attached to a dynamic financial market. Initial public offerings and capital increases by public offering have strong motivations for excessive avoidance from British firms. Table 6 indicates that leverage (LEV) is positively $(\beta 7=-0.189)$ related to tax avoidance for Japanese firms. However, it shows an insignificant association with tax avoidance for British firms. Salehi and Salami (2020 show that financial leverage use is not inversely regarding companies' tax-aggressive policies.

In the Japanese institutional context, bank credits largely lead to an increase in tax evasion in order to avoid violating debt covenants. The increase in net profit symbolizes an optimistic indicator for lenders, especially financial institutions, who want to continue to provide funds to businesses on decent terms. Firm size (SIZE) and profitability (ROA) are not associated with less significant tax evasion behavior. Besides

Table 6 supports hypothesis H5. The results show that the differences in tax evasion can be explained by the cultural and legal differences between the two countries. In a code law county such as Japan, the company has a small degree of flexibility to improve its governance system, even if there is a need for this transformation. Although public and institutional shareholders have a growing role in diversifying the board, boards of directors of large listed firms do not show signs of greater gender diversity 
(Morikawa 2016). This result can be explained by the additional control bodies installed in large companies to reduce agency costs. Complementary monitoring is more important in code law countries where the company's management is organized by several laws and regulations. Although board size (BS), independent directors (IND), and ownership concentration (CONC) have a negative impact on corporate tax avoidance in Japanese firms, only BS is statistically significant. However, for the British firms, these variables are all statistically significant. So, the impact of corporate governance mechanisms is more effective in common law countries than in code law countries.

Our results show that the impact of a country's legal system is a significant factor in explaining the relationship between specific corporate governance mechanisms and corporate tax avoidance means. The results similarly suggest that companies in common law countries have better governance. These companies do not intend to engage in tax evasion activities in the same way companies with a similar level of governance and which operate in code law countries do. More explicitly, for the entire sample, we find that the regression coefficients for BS, IND, and WOW are negative and significant in Table 5.

We found the same results for the British sample of 312 firm-year observations in Table 6. However, only board size (BS) has a significant coefficient for the Japanese sample. Board size, independent directors, the presence of women on boards of directors, and ownership concentration reduce the disparity between the statutory tax rate and the effective tax rate; thus, they reduce the likelihood of becoming tax avoidant in UK context.

Generally, firms with high debt ratios tend to manage their effective tax rates downward. This result, in Japan, seems to indicate a substitution effect between control by debt and control by shareholders and the board of directors. This result is consistent with several studies that support the hypothesis that the use of debt and the governance structure are two substitutable control mechanisms (Richardson et al. 2014; Chava et al. 2019). This divergence with the British context is indeed linked to the specificity of the Japanese banking context, which is based more on debt.

\section{Conclusion}

To the best of the authors' knowledge, this is the first paper to provide an empirical comparison between British and Japanese firms to study the impact of board characteristics and ownership identity on tax avoidance. More particularly, it compares the impact of governance mechanisms in two different legal contexts. This study contributes to the existing literature that focuses on the tax behavior of firms. By integrating the concerns of large accounting firms and the theory that suggest that the risk of aggressive tax planning should be taken into account by the board of directors and shareholders, we investigated different features that would allow better advice concerning this risk. 
Based on a sample of British and Japanese firms over the 2012-2017 period, the results show a positive and significant association between board size, independent directors and ownership concentration, and the effective tax rate (ETR). Thus, these variables reduce the likelihood of corporate tax avoidance. However, we found an insignificant association between female directors and tax avoidance. We also found that the consequence of a country's legal system (British common law and Japanese law code) is important in explaining the relationship between tax evasion and the general level of corporate governance in a given country. The results also suggest that the role of corporate governance is stronger for companies operating in common law countries than those in code countries.

This paper makes several contributions to the existing literature by exploring the consequence of corporate governance on tax evasion in two diverse legal systems (common law versus code of law). Corporate governance mechanisms are expensive; regulators need to before applying for corporate governance mechanisms in their country. Countries that have complied with the rules can change their corporate governance rules by adopting certain rules in the firms. The paper's findings provide unique and useful information for company stakeholders and managers aiming to address the factors that enhance firms' incentives to engage in aggressive tax practices.

According to Pukeliene and Kažemekaityte (2016), the subject of tax evasion is a strategic priority for the European Union (as indicated in the annual growth survey for the European Union in 2016). However, there is still no strategy for the implementation of national tax compliance policy recommendations based on the determinants of tax evasion.

Regarding the corporate governance of Central and Eastern European countries (for example, Poland), it connected with the tradition of the German governance model due to close historical and economic ties. We can go along with the idea of Russo et al. (2015), who proposed that differences in Polish corporate governance must adapt to those with a history of success. Central and Eastern European countries must take into account the common positive characteristics of the two governance systems (UK and Japanese), in particular, the strengthening of transparency, accountability, investor protection, and business ethics; consequently, they will reduce tax evasion.

These results must, however, be interpreted taking into account certain limitations. Indeed, the criterion of accounting and financial expertise of the members of the audit committee and the nature of the shareholding (managerial shareholding, family shareholders, institutional investors, etc.) were not taken into account in our empirical study. These criteria that act as governance mechanisms could likely have a significant impact on opportunistic accounting practices. The most important limitation lies in the fact that our study covers a limited period and includes only large British and Japanese firms. Thus, our results may not be generalizable to smaller companies and different time frames. In addition, the lack of systematic tax avoidance measurement for other groups of companies imposes certain limitations on the generalizability of the findings. In the future, The inclusion of medium-sized firms might improve the research design. 


\section{References}

Adams, R., Ferreira, D. (2009), Women in the boardroom and their impact on governance and performance, "Journal of Financial Economics", 94, pp. 291-309. https:// doi.org/10.1016/j.jfineco.2008.10.007

Anderson, A., Gupta, P. (2009), A cross-country comparison of corporate governance and firm performance: Do financial structure and the legal system matter?, "Journal of Contemporary Accounting and Economics”, 5 (2), pp. 61-79. https://doi.org/10.10 16/j.jcae.2009.06.002

Anderson, C.R., Reeb, M.D. (2003), Founding-family ownership and firm performance: Evidence from the S\&P 500, “The Journal of Finance”, 58 (3), pp. 1301-1327. https:// doi.org/10.1111/1540-6261.00567

Armstrong, C., Blouin, J., Jagolinzer, A.D., Larcker, D.F. (2015), Corporate governance, incentives, and tax avoidance, "Journal of Accounting and Economics" 60 (1), pp. 1-17. https://doi.org/10.1016/j.jacceco.2015.02.003

Austin, C.R., Wilson, R.J. (2017), An examination of reputational costs and tax avoidance: Evidence from firms with valuable consumer brands, "Journal of the American Taxation Association”, 39 (1), pp. 67-93. https://doi.org/10.2308/atax-51634

Badertscher, B., Katz, S., Rego, S. (2013), The separation of ownership and control and corporate tax avoidance. "Journal of Accounting and Economics", 56, pp. 228-250. https://doi.org/10.1016/j.jacceco.2013.08.005

Beekes, W., Brown, P., Zhan, W., Zhang, Q. (2016), Corporate Governance, Companies" Disclosure Practices and Market Transparency: A Cross Country Study, "Journal of Business Finance \& Accounting”, 43, pp. 263-297. https://doi.org/10.1111/jb fa. 12174

Bird, A., Karolyi, S. (2017), Governance and Taxes: Evidence from Regression Discontinuity, “The Accounting Review”, 92 (1), pp. 29-50. https://doi.org/10.2308/accr51520

Boone, A.L., Field, L.C., Karpoff, J.M., Raheja, C.G. (2007), The determinants of corporate board size and composition: An empirical analysis, "Journal of Financial Economics”, 85 (1), pp. 66-101. https://doi.org/10.1016/j.jfineco.2006.05.004

Cabello, O., Gaio, L. and Watrin, C. (2019), Tax avoidance in management-owned firms: evidence from Brazil", "International Journal of Managerial Finance", 15 (4), pp. 580-592. https://doi.org/10.1108/IJMF-04-2018-0117

Chan, K., Mo, P.L., Tang, T. (2016), Tax Avoidance and Tunnelling: Empirical Analysis from an Agency Perspective, "Journal of International Accounting Research", 15 (3), pp. 49-66. https://doi.org/10.2308/jiar-51345

Chava, S., Fang, S., Kumar, P., Prabhat, S. (2019), Debt Covenants and Corporate Governance, "Annual Review of Financial Economics", 11, pp. 197-219. https://doi .org/10.1146/annurev-financial-110716-032511

Chen, S., Chen, X., Cheng, Q., Shevlin, T. (2010), Are family firms more tax aggressive than non-family firms?, "Journal of Financial Economics", 95, pp. 41-61. https://doi .org/10.1016/j.jfineco.2009.02.003

Chytis, E., Tasios, S. and Filos, I. (2020), The effect of corporate governance mechanisms on tax planning during financial crisis: an empirical study of companies listed 
on the Athens stock exchange, "International Journal of Disclosure and Governance", 17, pp. 30-38. https://doi.org/10.1057/s41310-020-00072-3

Claessens, S., Djankov, S., Lang, L.H.P. (2000), The separation of ownership and control in East Asian corporations, "Journal of Financial Economics", 58, pp. 81-112. https://doi.org/10.1016/S0304-405X(00)00067-2

Coles, J.C., Daniel, N.D., Naveen, L. (2008), Boards: Does one size fit all?, "Journal of Financial Economics” 87 (2), pp. 329-356. https://doi.org/10.1016/j.jfineco.2006.08.008

Crocker, K., Slemrod, J. (2005), Corporate tax evasion with agency costs, "Journal of Public Economics”, 89, pp. 1593-1610. https://doi.org/10.1016/j.jpubeco.2004.08 .003

Daniel, S.J., Cieslewicz, J.K., Pourjalali, H. (2012), The impact of national economic culture and country-level institutional environment on corporate governance practices, "Management International Review", 52, pp. 365-394. https://doi.org/10.1007 /s11575-011-0108-X

Desai, M., Dharmapala, D. (2008), The Review of Economics and Statistics, 91 (3), pp. 537-546. https://doi.org/10.1162/rest.91.3.537

Doidge, C., Karolyi, G., Stulz, R. (2004), Why are foreign firms listed in the US worth more?, "Journal of Financial Economics", 71, pp. 205-238. https://doi.org/10.1016 /S0304-405X(03)00183-1

Dyreng, S., Hanlon, M., Maydew, E. (2008), Long-run corporate tax avoidance, "The Accounting Review", 83, pp. 61-82. https://doi.org/10.2308/accr.2008.83.1.61

Dyreng, S.D., Hanlon, M., Maydew, E.L., Thornock, J.R (2017), Changes in corporate effective tax rates over the past twenty-five years, "Journal of Financial Economics”, 124 (3), pp. 441-463. https://doi.org/10.1016/j.jfineco.2017.04.001

Fama, E.F., Jensen, M.C. (1983), Separation of ownership and control, "Journal of Law and Economics", 26, pp. 301-325. https://doi.org/10.1086/467037

Filatotchev, I., Jackson, G., Nakajima, C. (2013), Corporate governance and national institutions: A review and emerging research agenda, "Asia Pacific Journal of Management”, 30 (4), pp. 965-986. https://doi.org/10.1007/s10490-012-9293-9

Goh, B.W., Lee, J., Lim, C.Y., Shevlin, T. (2016), The Effect of Corporate Tax Avoidance on the Cost of Equity, "The Accounting Review”, 91 (6), pp. 1647-1670. https://doi .org/10.2308/accr-51432

Gregory-Smith, I., Main, B.G.M., O’Reilly III , C.A. (2014), Appointments, pay and performance in UK boardrooms by gender, "Economic Journal", 124, pp. 109-128. https://doi.org/10.1111/ecoj.12102

Gul, F., Khedmati, M., Shams, S. (2018), Managerial acquisitiveness and corporate tax avoidance“, p. 27, https://doi.org/10.1016/j.pacfin.2018.08.010

Hair, J.F., Black, W.C., Babin, B.J., Anderson, R.E., Tatham, R.L. (2006), Multivariate Data Analysis, $6^{\text {th }}$ ed. Pearson Prentice-Hall, Upper Saddle River, NJ.

Hanlon, M., Heitzman, S. (2010), A review of tax research, "Journal of Accounting and Economics”, 50, pp. 127-178. https://doi.org/10.1016/j.jacceco.2010.09.002

Hanlon, M., Slemrod, J. (2009), What does tax aggressiveness signal? Evidence from stock price reactions to news about tax shelter involvement, "Journal of Public Economics”, 93, pp. 126-141. https://doi.org/10.1016/j.jpubeco.2008.09.004 
Hoseini, M., Safari Gerayli, M., Valiyan, H. (2019), Demographic characteristics of the board of directors structure and tax avoidance: Evidence from Tehran Stock Exchange, "International Journal of Social Economics", 46 (2), pp. 199-212. https:// doi.org/10.1108/IJSE-11-2017-0507

Huseynov, F., Sardarli, S., Zhang, W. (2017), Does Index Addition Affect Corporate Tax Avoidance?, "Journal of Corporate Finance", 43, pp. 241-259. https://doi.org/10.10 16/j.jcorpfin.2017.01.008

Janský, P. (2019), Effective Tax Rates of Multinational Enterprises in the EU, A Report Commissioned by The Greens/EFA Group in The European Parliament. https:// www.greens-efa.eu/fr/article/document/effective-tax-rates-for-multination-compa nies-in-the-eu/ (accessed: 21.01.2019).

Jarboui, A., Kachouri Ben Saad, M., Riguen, R. (2020), Tax avoidance: do board gender diversity and sustainability performance make a difference?, "Journal of Financial Crime”, Emerald ahead-of-print, https://doi.org/10.1108/JFC-09-2019-0122

Jensen, M. (1993), The modern industrial revolution, exit, and the failure of internal control systems, "Journal of Finance", 48, pp. 831-880. https://doi.org/10.1111/j.15 40-6261.1993.tb04022.x

Jensen, M., Meckling, W. (1976), Theory of the firm: managerial behavior, agency costs and ownership structure, "Journal of Financial Economics", 3, pp. 305-360. https:// doi.org/10.1016/0304-405X(76)90026-X

Kanagaretnam, K., Lee, J., Lim, C.Y., Lobo, G.J. (2016), Relation between Auditor Quality and Tax Aggressiveness: Implications of Cross-Country Institutional Differences. AUDITING: "A Journal of Practice \& Theory", 35 (4), pp. 105-135. https://doi.org /10.2308/ajpt-51417

Khan, M., Srinivasan, S., .Tan L (2017), Institutional Ownership and Corporate Tax Avoidance: New Evidence, “The Accounting Review” 92 (2), pp. 101-122. https:// doi.org/10.2308/accr-51529

Klapper L., Love, I. (2004), Corporate governance, investor protection, and performance in emerging markets, "Journal of Corporate Finance", 10, pp. 703- 728. https://doi .org/10.1016/S0929-1199 (03)00046-4

Klassen, K.J. (1997), The Impact of Inside Ownership Concentration on the Trade-Off between Financial and Tax Reporting, "The Accounting Review", 72 (3), pp. 455474.

Kubíček, A., Štamfestová, P., Strouhal, J. (2016), Cross-Country Analysis of Corporate Governance Codes in the European Union, "Economics and Sociology", 9 (2), pp. 319-337. https://doi.org/10.14254/2071-789X.2016/9-2/22

La Porta, R., Lopez-de-Silanes, F., Shleifer, A., Vishny, R.W. (1998), Law and finance, "Journal of Politcal. Economy", 106, pp. 1113-1155. https://doi.org/10.1086/250042

La Porta, R., Lopez-de-Silanes, F., Shleifer, A., Vishny, R.W. (2002), Investor protection and corporate valuation. "Journal of Finance", 57 (3), pp. 1147-1170. https://doi.org /10.1111/1540-6261.00457

Lanis, R., Richardson G. (2011), The effect of board of director composition on corporate tax aggressiveness, "Journal of Accounting Public Policy", 30, pp. 5070. https://doi .org/10.1016/j.jaccpubpol.2010.09.003 
Lanis, R., Richardson, G., Liu, C., McClure, R. (2018), The Impact of Corporate Tax Avoidance on Board of Directors and CEO Reputation, "Journal of Business Ethics", June. https://doi.org/10.1007/s10551-018-3949-4

Liu, Y., Miletkov, M., Wei, Z., Yang, T. (2015), Board independence and firm performance in China, "Journal of Corporate Finance", 30, pp. 223-244. https://doi.org/10 .1016/j.jcorpfin.2014.12.004

Luo, J., Xiang, Y., Huang, Z. (2017), Female directors and real activities manipulation: Evidence from China, "China Journal of Accounting Research", 10 (2), pp. 141-166. https://doi.org/10.1016/j.cjar.2016.12.004

Mafrolla, E., D’Amico, E. (2016), Tax aggressiveness in family firms and the non-linear entrenchment effect, "Journal of Family Business Strategy" 7 (3), pp. 178-184. https://doi.org/10.1016/j.jfbs.2016.08.003

McGuire, S.T., Wang, D., Wilson, R.J. (2014), Dual Class Ownership and Tax Avoidance, “The Accounting Review”, 89, pp. 1487-1516. https://doi.org/10.2308/accr-50718

Minnick, K., Noga, T. (2010), Do corporate governance characteristics influence tax management?, "Journal of Corporate Finance", 16, pp. 703-718. https://doi.org/10 .1016/j.jcorpfin.2010.08.005

Morikawa, M. (2016), What types of companies have female directors? Evidence from Japan, "Japan and the World Economy" pp. 37-38. https://doi.org/10.1016/j.japwor .2015.09.001

Mork, R., Shleifer, A., Vishney, R.W. (1998), Management ownership and market valuation, "Journal of Financial Economics", 20, pp. 293-315. https://doi.org/10.10 16/0304-405X(88)90048-7

Muhammad, Ansar Ma, Chaom, Y. (2019), Financial statement comparability and corporate tax avoidance: evidence from China, "Economic Research-Ekonomska Istraživanja”, 32 (1), pp. 1813-1843. https://doi.org/10.1080/1331677X.2019.1640627

Munisi, G., Hermes, N., Randøy, T. (2014), Corporate boards and ownership structure: Evidence from Sub-Saharan Africa, "International Business Review", 23 (4), pp. 785-796. https://doi.org/10.1016/j.ibusrev.2013.12.001

Nguyen, T., Locke, S., Reddy, K. (2015), Ownership concentration and corporate performance from a dynamic perspective: Does national governance quality matter?, "International Review of Financial Analysis", 41, pp. 148-161. https://doi.org/10.10 16/j.irfa.2015.06.005

Nguyen, P., Rahman, N., Tong, A., Zhao, R. (2016), Board size and firm value: evidence from Australia, "Journal of Management \& Governance", 20 (4), pp. 851-873. https:// doi.org/10.1007/s10997-015-9324-2

Ortas, E., Gallego-Álvarez, I. (2020), Bridging the gap between corporate social responsibility performance and tax aggressiveness: The moderating role of national culture, "Accounting, Auditing \& Accountability Journal”, ahead-of-print. https:// doi.org/10.1108/AAAJ-03-2017-2896

Pukeliene, V., Kažemekaityte, A. (2016), Tax behaviour: assessment of tax compliance in European Union countries, "Ekonomika", 95 (2), pp. 30-56. https://doi.org /10.15388/Ekon.2016.2.10123

Reguera-Alvarado, N., Bravo, F. (2017), The effect of independent directors characteristics on firm performance: Tenure and multiple directorships, "Research in Inter- 
national Business and Finance" 41, pp. 590-599. https://doi.org/10.1016/j.ribaf.20 17.04.045

Richardson, G., Lanis, R., Chi-Moon Leung, S., (2014), Corporate tax aggressiveness, outside directors, and debt policy: An empirical analysis, "Journal of Corporate Finance”, 25(C), pp. 107-121. https://doi.org/10.1016/j.jcorpfin.2013.11.010

Richardson, G., Taylor, G., Lanis, R., (2016), Women on the board of directors and corporate tax aggressiveness in Australia: An empirical analysis, "Accounting Research Journal”, 29 (3), pp. 313-331. https://doi.org/10.1108/ARJ-09-2014-0079

Richardson, G., Wang, B., Zhang, X. (2016), Ownership structure and corporate tax avoidance: Evidence from publicly listed private firms in China, "Journal of Contemporary Accounting and Economics”, 12 (2), pp. 141-158. https://doi.org/10.10 16/j.jcae.2016.06.003

Russo, A., Herdan, A., Neri, L. (2015), Empirical evidence on internal control disclosure in Italy Stock Exchange and Polish Stock Exchange, [in:] Współczesne uwarunkowania sprawozdawczości i rewizji finansowej, Kraków, pp. 379-388.

Salehi, M., Salami, S. (2020), Corporate tax aggression and debt in Iran, "Journal of Islamic Accounting and Business Research”, 1 (1), pp. 257-271. https:// doi.org/10.1108/JIABR-10-2016-0127

Shackelford, D.A., Shevlin, T. (2001), Empirical tax research in accounting, "Journal of Accounting and Economics", 31 (1-3), pp. 321-387. https://doi.org/10.1016/S01 65-4101 (01)00022-2

Slemrod, J. (2007), Cheating Ourselves: The Economics of Tax Evasion, "Journal of Economic Perspectives”, 21 (1), pp. 25-48. https://doi.org/10.1257/jep.21.1.25

Tang, Y., Liu, Y., Liu, J., Li, W. (2019), Does More Managerial Power Impede or Promote Corporate Tax Avoidance? Evidence from Listed Chinese Companies, "Sustainability", 11 (7), p. 1-18.

Terjesen, S., Couto, E.B., Francisco, P.M. (2016), Does the presence of independent and female directors impact firm performance? A multi-country study of board diversity, "Journal of Management and Governance", 20 (3), pp. 447-483. https://doi.org/10 .1007/s10997-014-9307-8

Thomsen., M., Watrin, Ch. (2018), Tax avoidance over time: A comparison of European and US firms, "Journal of International Accounting, Auditing and Taxation", 33(C), pp. 40-63. https://doi.org/10.1016/j.intaccaudtax.2018.11.002

Yeoh, P. (2007), Corporate governance models: Is there a right one for transition economies in Central and Eastern Europe?, "Managerial Law", 49 (3), pp. 57-75. https:// doi.org/10.1108/03090550710816483

Yermack, D. (1996), Higher market valuation of companies with a small board of directors. "Journal of Financial Economics", 40, pp. 185-212. https://doi.org/10.1016/03 04-405X(95)00844-5

Zeng, T. (2019), Country-level governance, accounting standards, and tax avoidance: a cross-country study, "Asian Review of Accounting”, 27 (3), pp. 401-424.

Zimmerman, J. (1983), Taxes and firm size, "Journal of Accounting and Economics", 5 (2), pp. 119-149. https://doi.org/10.1108/ARA-09-2018-0179 


\section{Streszczenie}

\section{Ład korporacyjny a unikanie zobowiązań podatkowych - porównanie przedsiębiorstw brytyjskich i japońskich}

Celem niniejszego artykułu jest zbadanie wpływu ładu korporacyjnego na unikanie zobowiązań opodatkowych w ujęciu międzynarodowym.

W badaniu wykorzystano dane finansowe i dotyczące tadu korporacyjnego dla wybranych przedsiębiorstw japońskich i brytyjskich z okresu 2012-2017, pochodzące z bazy danych Datastream. Najpierw zbadano bezpośredni wpływ kilku mechanizmów ładu korporacyjnego na unikanie zobowiązań podatkowych. Następnie dokonano podziału wybranych przedsiębiorstw na dwie grupy (oparte o system prawa zwyczajowego i system prawa kodeksowego), aby zbadać związek między systemem prawa, tadem korporacyjnym, a unikaniem zobowiązań podatkowych. Do weryfikacji sformułowanych hipotez zastosowano zarówno jednoczynnikowe metody regresji, jak i Stosowalną Uogólnioną Metodę Najmniejszych. Kwadratów (FGLS).

Badanie wykazało, że wielkość zarządu, występowanie niezależnych dyrektorów oraz obecność kobiet w zarządach, zmniejszają prawdopodobieństwo unikania zobowiązań podatkowych. Zaobserwowano jednak nieistotny związek między koncentracją własności a unikaniem zobowiązań podatkowych. Wykazano również, że przedsiębiorstwa w krajach o wyższym poziomie zarządzania na szczeblu krajowym są mniej podatne na unikanie zobowiązań podatkowych. Wyniki sugerują też, że rola ładu korporacyjnego jest większa w przypadku firm działających w krajach opartych o system prawa zwyczajowego niż w krajach opartych o system prawa kodeksowego.

Opracowanie jest jednym z nielicznych badań, które badają związek między ładem korporacyjnym a unikaniem zobowiązań podatkowych w ujęciu międzynarodowym, z uwzględnieniem różnic w otoczeniu prawnym i instytucjonalnym. Związek ten jest różny w zależności od kraju. W tym artykule wyraźnie wskazano implikacje dla badań naukowych, praktyki i społeczeństwa. Wykazano w nim, że wdrożenie przez państwo prawidłowego systemu zarządzania, którego celem jest poprawa przejrzystości i odpowiedzialności, umożliwia ograniczenie unikania zobowiązań podatkow przez przedsiębiorstwa.

Słowa kluczowe: unikanie zobowiązań podatkowych, ład korporacyjny, porównanie systemów prawnych 